\title{
brazilianpoliticalsciencereview
}

\author{
REVIEW ESSAY
}

\section{The Genesis of Participatory Democracy in Brazil: a Scientific (Re)Construction*}

\author{
Marie-Hélène Sa Villas Boas \\ Université Nice Sophia Antipolis, France
}

The rise of participatory democracy has often been explained by the renewal of collective action in Europe and Latin America. This review essay questions the 'movement-based' genesis of Brazilian participatory democracy by analyzing the idea of the state upon which it rests. It argues that the focus on social movements falls short of explaining the spread of participatory experiments, and that it rests on a simplified understanding of the dynamics of the Brazilian State prior to the 1980s. The argument is developed along three axes. First, the essay analyses how the 'classics' of Brazilian political sociology framed the early studies on participatory democracy. Second, it shows that even if the unifying notion of the state has been challenged, progress has focussed on the study of the democratic period. Third, it presents evidence that participation, as a practical category, was an integral part of the military regime's discourse and practice. Finally, the essay defines lines of investigation to reconsider the origins of participatory democracy in Brazil.

Keywords: Participatory democracy; Brazil; political sociology.

(*) http://dx.doi.org/10.1590/1981-3821201700010008

The author thanks the BPSR's anonymous reviewers for their helpful and constructive comments as well as Clare Tame, for her support on English revision. 
he genesis of participatory democracy in Brazil has often been explained in terms of the renewal of collective action in Europe and Latin America. This 'movement-based' interpretation of the genesis links social movements with the creation of new procedures based on the notion of citizen participation. It had, for example, been the interpretational framework applied to early participatory practices in France, such as the Municipal Action Groups (GAM) of the 1960s and 1970s. This was before it was challenged by scholars, who demonstrated the simultaneous changes taking place in public action (BLATRIX, 2000).

A similar process can be observed in Brazil. If civil society was the main protagonist of a first wave of analysis, the development of a broad field of studies on Brazilian experiments led to a more balanced view of the promoters of participatory democracy (DAGNINO, OLVERA and PANFICHI, 2006), including political elites and international organizations such as the World Bank (WAMPLER, 2008). Yet if the scope of the analysis has been broadened to obtain a better understanding of the changes generated by participatory institutions in democratic Brazil, the starting point is still related to the emergence of 'new actors', namely new social movements (WAMPLER, 2015) and the party historically associated with them, the Workers Party (AVRITZER, 2009; KECK, 1991). For example, according to Avritzer (2009), participation "has as its starting point the emergence of a new associative civic culture. Beginning in the 1970s, voluntary associations began to grow in diversity and density across Brazil, transforming the country's public sphere" (AVRITZER, 2009, p. 21).

This review essay questions this genesis by analyzing the notion of the State on which it rests. If the idea of a new and autonomous civil society which emerged in the 1970s has since been challenged by some authors (GURZA LAVALLE and SZWAKO, 2015), the same critical exercise has not occurred for the representation of Brazilian political institutions before the 1980s, at least in the field of participatory democracy studies.

Today it is generally accepted that the unifying and problem-centered notion of the State that underlies early work on participatory democracy had to be rethought to understand the new experiments taking place (DAGNINO, OLVERA and PANFICHI, 2006). Yet the analytical progress brought about by this shift is often limited to the study of the democratic period, that is, from the 1980s onwards. Before the authoritarian breakdown, the 'State', as a set of political institutions, actors and practices at the federal 
and local levels, still appears as a homogenous and unified entity. In this essay I argue that this starting point prevents us from understanding: first, the multiple processes and actors that may have contributed to the consolidation of participatory democracy; and second, the changes brought by participatory institutions in democratic Brazil. Without a precise insight into the forms of public action prior to the 'innovations' created from the 1980s onwards, it is difficult to determine the type and extent of the changes generated by models of participatory democracy.

However, the negative and homogeneous notion of the State, as the "incarnation of evil" to use the expression of Evelina Dagnino and Luciana Tatagiba (2010), is not necessarily the result of a deliberate bias. To understand it, we need to take into account the academic legacy on which it rests; that is, the way the 'classic works' of Brazilian political sociology have analyzed the specific trajectory of the State. In other words, we need to study the conceptual framework that sustains the genesis of participatory democracy. Without slipping into scientific relativism, which would reduce evidence to the context within which it is produced, such an approach reminds us that in order to understand the first, we also need to comprehend the second.

In order to understand the genesis of participatory democracy in Brazil, the first section analyses the conception of Brazil's history 'constructed' in the classical works of Brazilian political sociology. The second section shows that the latter inspired a first wave of studies on participatory democracy, where the 'problems' of the State were set against the renewal of social movements. This perspective has now been challenged and surpassed, but the progress has focused on the democratic period. The third section presents evidence that the notion of 'participation', especially by the poor, was used during the military regime, both by those who governed and their opponents, albeit with different meanings. This is an invitation to make the notion of the State prior to the 1980s more complex. The last part proposes some lines of further investigation.

\section{Dysfunctioning representative democracy in classical Brazilian political sociology}

One of the shared convictions of observers of participatory democracy is the anomaly of Brazilian representative democracy before the 1980s. This was reduced to the categories used to describe it, such as patrimonialism or clientelism. The country's political system has been seen as a problem that could be solved by participatory institutions. More generally, the dysfunctions of representative democracy are the 
starting point of participation and deliberative theory (BARBER, 1984; PATEMAN, 1970). In Europe, a similar correlation is made when scholars explain the diffusion of participatory models as a response to the 'crisis' of representative democracy. Yet in Brazilian sociology, the image of this damaged representative system was also accepted due to the support it enjoyed thanks to the notion of the Brazilian State 'constructed' by classical political theory.

\section{History of a democratic anomaly}

According to Bolivar Lamounier (2005),

representative mechanisms (elections, parties and legislative assembly) have always been the target par excellence of national skepticism. Since its origins in the nineteenth century, representative democracy has been questioned by politicians, intellectuals and journalists, who view it as an imported superstructure, an "idea out of place", a result of the utopian idealism of a ruling elite or, worse, a cynical instrument of domination serving the large land-owners (LAMOUNIER, 2005, p. 15).

Indeed, scholars of the political system have tried, in different ways, depending on the historical period, to highlight the pathological nature of Brazil's political organization, particularly at the local level. From the perspective of classical social science, democratic anomalies and local power are seen as being tightly linked.

Between 1920 and 1940 politically engaged intellectuals ${ }^{1}$, who produced the early analyses of Brazilian political organization, often argued that representative institutions were not adapted to the Brazilian 'reality' (PÉCAUT, 1990, pp. 46-49). The First Republic, or 'Old Republic' (1889-1930), was seen as a failed importation (BADIE, 1992). Far from ending the forms of domination established during the colonial period, the representative system is supposed to have institutionalized them.

This is exemplified in the work of the conservative José Francisco Oliveira Vianna (1949) for whom the type of colonization pursued by colonial Portugal, based on the allocation of land to representatives of the Portuguese monarchy on Brazilian territory ${ }^{2}$, gave rise to a fragmented and privatized political system, ruled by a restricted

\footnotetext{
${ }^{1}$ According to Pécaut (1990), these intellectuals were not academics but lawyers, engineers and men of letters (PÉCAUT, 1990, pp. 33-42). Their profile must be linked to the characteristics of academe, which really developed as of the 1930s (MOTA, 2008, pp. 74-75).

2 The colonial political organisation was based on fourteen 'hereditary captaincies' under the authority of the governor general and the viceroy.
} 
elite of 'landed gentry'. The political organization during the colonial period would not have allowed the creation of an independent public sphere. This legacy explains the particularist political practices of large landowners during the First Republic (VIANNA, 1923; 1949). Vianna (1949) concludes that representative institutions are ill-suited to Brazilian politics since the electoral process has not weakened the domination of the oligarchy, but has instead preserved it (DAVIDOFF, 1982; COSTA, 2005).

Vianna's anti-liberal conception was shared by many conservative authors, such as Nestor Duarte (1939), and reproduced the 'rhetoric of reaction' (HIRSCHMAN, 1991). Yet their critique of representative institutions was also sustained by liberal authors. In 1936, Sérgio Buarque de Holanda published his 'Raízes do Brasil', described as an article by its author, but considered a landmark in Brazilian social science literature. According to Buarque de Holanda (1936),

democracy in Brazil has always been a lamentable misunderstanding. A rural and semi-feudal aristocracy imported it and tried to make it compatible, as far as possible, with its privileges [...]. It introduced in a traditional situation, at least as a facade or an external ornament, the slogans that seemed more suitable to the period and that were exalted in books and discourse [...]. It is undeniable that in our political life [...] the liberal democracy motto is only ornamental and declamatory, not deeply-rooted in Brazilian reality. (HOLANDA, 2006, pp. 160, 183)

The evaluation that representative institutions are not adapted to Brazilian political life goes hand in hand with a critique of the strict reproduction of the ruling elite, regardless of regime changes.

Nevertheless, in order to be properly understood, these studies need to be placed in the context in which they have been produced. Daniel Pécaut (1990) shows that in the period 1925-1940, intellectuals played an increasing role in political life. They defended an institutional renewal for a Republic judged as being too supportive of local oligarchs. The denouncement of liberal democracy was bound up with the political position of authors, such as Vianna (1974), who worked to promote the creation of a strong central state. At that time, most studies expanded on the perverse effects of the importation of the representative system by republican elites. This system was perceived as being manipulated by 'traditional' political elites and hence unsuitable for the national 'reality' that scholars had partly constructed in their work (PÉCAUT, 1990). 
After the authoritarian regime or 'Estado Novo' (1937-1945)3, the causes of Brazilian political 'underdevelopment' were re-examined in a context of university consolidation. In 1958, in 'Os donos do poder', Raymundo Faoro (2001) produced a new interpretation of the trajectory of the Brazilian state, according to which the colonial period led to the formation of a patrimonial, rather than a feudal, State, a type of regime consolidated during the First Republic. By parceling out land to selected representatives, the Portuguese monarchy created a bureaucratic oligarchy (estamento burocrático) that imposed a centralized and hierarchical political system on Brazil (FAORO, 2001). The reason why the Brazilian State has never been based on universality and neutrality is that bureaucrats controlled the economy and used it to serve their own interests (CAMPANTE, 2003). This interpretation offers a different view of the trajectory taken by the Brazilian state, but it still reproduces the idea that representative structures are not appropriate for Brazil. According to Faoro (2001, p. 822), "historical reality has proved the secular continuity of patrimonial structure", from the sixteenth century to the 1930s, irrespective of regime changes. This historical continuity has hindered the emergence of a 'real' Brazilian culture: imported institutions produced an illusive representative system, consisting of "masters who do not originate in the nation, from society or from the ignorant and poor people" (FAORO, 2001, p. 837).

In the period 1920-1950 early political studies converge in their assessment that representative principles are unsuitable for Brazilian political life. In these classic studies, the construction of the Brazilian State seems to follow a deviant path, in comparison with the representative ideals valued by political theory. This deviation is explained by political practices at the local level.

Ana Cleide Chiarotti (1986) shows that, until the 1950s, the social sciences constructed the idea of a 'culture of backwardness' at the local level, revealed by "the oligarchic nature of politics, where conflicts do not have any ideological foundations but are based on particularism" (CHIAROTTI, 1986, p. 77). This thesis is not specific to Brazilian political sociology, and a similar notion was developed in France for centreperiphery relations (JOANA, 2000). Yet in Brazilian studies, the culture of local-level backwardness is an explanatory factor of anomalies in political organization.

3 The 'Estado Novo' was a period of authoritarian government and populism in Brazil. It was represented by Gétulio Vargas who led the 1930 Revolution that ended with the First Republic. During the 'Estado Novo', political rights were suspended whereas some social rights had been created, although only for regular workers. 
For Vianna (1974), the weight accorded to governors during the First Republic was a key obstacle to the pursuit of a general interest that could only be ensured through the national State (VIANNA, 1974, pp. 56-58). Although this view is strongly linked to the ideological position of its author and to the context in which it is expressed, it has been reproduced in other works. In his book on 'coronelismo', written in 1948, Victor Nunes Leal (1975) takes a more sociological approach to the study of relations between the central and local state, while pointing out that local political practices are based on archaism and particular interests (FORTUNATO, 2000, p. 07). Leal (1975) focuses on the economic dimensions of oligarchic domination during the First Republic. In contrast to the formerly dominant continuum thesis, he shows that the inauguration of a representative regime brought about change. It forced the landed gentry to find new strategies to prevent their decline. 'Coronelismo' is a mutual support system for state governors and the landed gentry. During the First Republic the 'coroneis' provided the electoral support of those living in their municipalities to the governor of their state in exchange for financial and political benefits, which, in turn, boosted their legitimacy in their territory.

Although Leal's book (1975) relies on a careful analysis of the relational nature of political domination in Brazil, it reproduces the assessment that the representative system is unsuited to Brazilian 'reality'. Indeed his thesis is that 'coronelismo' was generated by "the superposition between advanced forms of representative regime and an inadequate socio-economic structure" based on particularism and the exchange of favors (LEAL, 1975, p. 40).

This idea was reinforced by Raymundo Faoro (2001) for whom the domination of the 'coroneis' and their particularist practices coexist alongside the bureaucratic state, characterized by a constant exchange of favours between bureaucrats, elected representatives and citizens, at the three levels of government of the Brazilian federation (FAORO, 2001, pp. 718-719). Clientelism is therefore supposed to be coexistent with Brazil's patrimonial state.

In the 1950s, 'coronelismo' and clientelism become key categories when it came to measuring social and institutional relations at the local level. If used in a sociological perspective, they also aim at highlighting how backwardness at the local level obstructs political modernization.

From the 1960s onwards, studies on the ruling elite and the political system 
gave way to works on economic organization, in a national-developmentalist or nationalMarxist perspective. In these studies, political dynamics are left in the background, whereas working-class struggle or the international division of labor become key explanations of Brazil's 'problems'. The political organization is once again challenged from the 1970s onwards, during the process of regime democratization.

\section{In search of democratisation}

In the late 1970s, the liberalization of the military regime coexisted with a renewal of the critique of Brazil's political organization and the democratic ideal became central in academic discourse. This process went hand in hand with the rediscovery of 'civil society'. According to Pécaut (1990), the support for democracy means a break with the idea, formerly common among Brazil's intellectuals, that the State should be the principal agent of social formation. From then on the existence of autonomous social movements has been defined as a precondition of democracy (PÉCAUT, 1990, p. 192). Therefore, the representative system was no longer seen as unsuitable for Brazilian society, but its principles were judged distorted in practice. Thus, in the 1980s several studies focused on the exercise of citizenship in Brazilian history and its structural lack of realization.

This shift is, firstly, the result of the development of political science, due to the increase of public resources allocated to education and research in the 1970s. The military regime wanted to base its action on precise 'social diagnostics', but it simultaneously tried to avoid harsh criticism and hence favored some types of research, in particular statistical research (KIRSCHNER and GOMES, 2008) over others. North American institutions, especially the Ford Foundation, also helped promote postdoctoral studies, particularly in Rio de Janeiro and Belo Horizonte (FORJAZ, 1997). Researchers trained in both institutions were influenced by U.S. approaches and methodology. They rejected the Marxist paradigm adopted in sociology because it negated the autonomy of politics and underestimated the role played by political institutions (KEINERT and SILVA, 2010). The socialization of new academic cohorts in newly-established research centres, and exchanges with North American universities ${ }^{4}$,

4 The trajectory of Wanderley Guilherme dos Santos and Fabio Wanderley Reis are representative. Director respectively of the University Institute of Rio de Janeiro (IUPERJ) and the Department of Political Science of the University of Minas Gerais (DCP-UFMG), they both 
contributed to the development of analysis inspired by their North American counterparts, based on the identification and diagnosis of Brazil's political 'anomalies' (REIS, 1978; SANTOS, 1979a).

This ambition was nevertheless offset by the relation of the young political science with 'Brazilian social thought'. This expression covers the studies of political sociology from 1920 to 1940 which trace the historical formation of Brazilian political institutions and social structures. This hybridization led to a renewed historical focus on the 'problems' of Brazilian democracy. If the ruling elite was the focus of work before the 1960s, citizenship started to become one of the main object of study and, in the late 1970s, the representative regime was no longer considered out of place in the Brazilian context. It was the bad application of its principles that would explain the failed realization of citizenship in Brazil.

For example, Guilherme Wanderley dos Santos (1979b) studies the citizenship regime consolidated from the 1930 onwards. He argues that the 'Estado Novo' created a 'regulated citizenship', which was based not on universal principles, but on the professional stratification formalized by law (SANTOS, 1979b), by means of the creation of distinctive classes of citizens and the exclusion of those working in the 'informal sector' from the social rights recognized in 1930. Citizenship is also presented as controlled by a State that 'contains' all forms of political participation. Thereafter, Santos (1998) uses his concept of 'regulated citizenship' to analyze the period 1946-1964 and shows that a similar process of State control and class exclusion can be observed during this democratic regime (SANTOS, 1998). From this perspective, Brazilian citizenship is strongly dependent on the State. The concept of 'regulated citizenship' has been criticized for its reductionism, since it is only based on the analysis of social rights 5 , focuses on trade-union participation and only considers State action in a negative way (REIS, 1991). Nevertheless it is frequently used to describe citizenship in Brazil.

During the transition to democracy, observers emphasize the State's control of political participation, and its corollary, the poor's exclusion from the body of citizens. The State is defined as a homogenous institution that had controlled, or snuffed out, any

graduated in Brazil, then took courses at the Economic Commission for Latin America (CEPAL) and obtained their PhDs at a prestigious North American university.

5 This notion is criticized by Teresa Cristina de Souza C. Vale who shows how we can challenge the work of Guilherme Wanderley dos Santos, by including political rights in the analysis, from 1930 to 1964 (VALE, 2008). 
type of autonomous political participation without guaranteeing real rights to its population ${ }^{6}$. The result is an unequal and atomized society, in which collective organizations are too dependent on State institutions. The State was now associated with a 'Leviathan', from which citizens must free themselves. Yet, this thesis cannot be detached from its context of expression, that is to say the collapse of the dictatorial regime.

Therefore, the (re)emergence of contentious collective action in the 1980s has been seen as a major change, particularly by social movement theorists. During the transition to democracy, two disciplinary sub-fields were consolidated and developed autonomously. The first analyses the functioning of political institutions and is principally, but not exclusively, based on quantitative methodology ${ }^{7}$. The second deals with social movements and has been developed in several research centres, in particular in the universities of São Paulo state. Scholars of collective action study the emerging forms of mobilisation during the 'pacted transition'. It is within this disciplinary subfield that the 'participationist' axis has been created.

For sociologists of collective action the mobilization cycle of the $1980 \mathrm{~s}$ is characterized by the birth of 'new actors' (DAGNINO, 1994; DOIMO, 1995; SADER, 1988), which differ from the pre-existing organizations developed under the aegis of the State. Camille Goirand (2010) highlights the considerable success of new social movement theory in Latin America. Until now it has been one of the main interpretational frameworks for the analysis of the organization of social movements. The discourse of 'autonomy' vis-à-vis political parties and the claim for political participation formulated by these actors seemed to symbolize new values (GOIRAND, 2010), based on the rejection of 'traditional practices' such as clientelism and State control. The study of new social movements led analysts of collective action, who sometimes took part in concerted public actions themselves, to postulate their transformative and democratizing potential against a State considered as authoritarian and a source of political and social exclusion (DAGNINO and TATAGIBA, 2010). Today this interpretational framework has been amended as a consequence of the changes that have taken place in the political system. Nevertheless it has influenced the study of

\footnotetext{
6 The same idea is developed by Francisco Weffort (1980) in his study of populism for the post1945 period.

7 The authors of this subfield focus on the study of 'pacted transition', coalition presidentialism or the electoral system represented by the journal Dados.
} 
participatory democracy.

\section{New actors vs. old state aillments}

Participationist studies initially drew on a conception of the State inherited from classic studies, namely an unrealized set of institutions. This perspective concealed the dynamics of a political field conceived as unified. It has been progressively challenged, so that the heterogeneity of the State is now accepted in most studies. Yet, this analytical revision has basically been applied to the democratic period.

\section{The bottom-up renewal of a traditional political field}

In the early works on participatory democracy in Brazil, the State is defined in line with the classical theory, as an excluding field where clientelistic and authoritarian forms of government prevail. This starting point emphasizes the novelty of participatory experiments, such as referenda, policy councils and participatory budgeting. Because these are supposed to constitute a break with the traditional functioning of the political sphere, they can only be the result of the mobilization of external actors, especially social movements.

One of the early works on institutional mechanisms based on the idea of popular participation is Maria Victoria de Mesquita Benevides' study (1996), 'A Cidadania Ativa', where she makes a careful analysis of the philosophical notions and historical process that led to the adoption of direct democracy procedures, such as referenda, plebiscites and popular initiatives. The starting point of her analysis is a revision of the Brazilian representative system, that she describes as a collection of political ills:

These ills of representation - and the reformist proposals - have been frequently analyzed by us. We can even say that it has been a favourite topic of Brazilian modern political science [...]. Most contemporary observers emphasize the political and social impediments to the consolidation of stable and reasonably democratic representative institutions. The classical theory of Raymundo Faoro on the exacerbated privatization of political power patrimonial State, conciliation and co-optation, the "owners of power" - as Sérgio Buarque de Holanda's skepticism - "democracy in Brazil has always been a lamentable misunderstanding" - are still key references (BENEVIDES, 1996, p. 26).

Benevides (1996) refers to these classical studies to remind us that the ideal of popular sovereignty is an illusion in a political system that can be defined by three 
features: 'coronelismo', clientelism and a non-representative party system (BENEVIDES, 1996, pp. 29-33). From this starting point, she defends the need to create new institutional procedures that would enhance popular participation.

If this work does not link the procedures studied exclusively with the renewal of social movements, the link between the creation of participatory institutions and urban associationism is first made more explicitly in relation to the study of participatory budgeting, especially in Porto Alegre. Two authors illustrate this move: Luciano Fedozzi and Leonardo Avriter.

Fedozzi's Master dissertation 'Do patrimonialismo à cidadania: participação popular na gestão municipal. 0 caso do orçamento participativo em Porto Alegre' subsequently published as 'Orçamento Participativo' (FEDOZZI, 1997) is partly based on the notion of the trajectory of the Brazilian State developed by Faoro (2001) and renewed by Schwartman (1988). For Fedozzi (1997), the patrimonial formation of Brazil means the construction of a tutelary power, where the State operates by co-option and exclusion; a lack of distinction between the public and private spheres and a duality between the real country and the formal one, expressed in the distance between the social and the institutional spheres.

Fedozzi's work has evolved significantly since the late 1990s, with stimulating new lines of research on the elitisation of participatory democracy (FEDOZZI and MARTINS, 2015). Yet, his work is still based on a stable conception of Brazilian State formation, as illustrates a more recent study that weighs up Porto Alegre's participatory budgeting:

Interpreted as a strategy to promote citizenship in Brazil, Participatory Budgeting therefore shifts away from the protracted authoritarian tradition that characterizes Brazilian society as recognized by many of the most important theorists of social formation (HOLANDA, 1993; FAORO, 2001; SCHWARTZMAN, 1988) (FEDOZZI, 2001, p. 93).

In contrast with this authoritarian framework, the contentious action of popular movements is seen as "a qualitative leap forward in overcoming the paternalistic practices (the act of asking for) and/or clientelist ones (exchange of favors)" (FEDOZZI, 2001, p. 97).

The second author who strongly opposes the logic of the political realm and that of social movements is Avritzer (2002), who takes a normative approach. He defines 
Brazilian political institutions as settings where traditional practices, especially clientelism, are reproduced. The institutional innovations introduced from the 1980s onwards are, therefore, seen as the result of external actors alone (ROMÃO, 2010). In Avritzer's perspective (2002), participatory democracy is the expression of a new civic culture, born within urban popular associations and which materialized in the shape of new institutions and procedures. To build this genesis of participatory institutions, Avritzer (2002, p. 44) occasionally relies on the classical studies mentioned in this article, especially Leal (1975), in order to recall the clientelist structure of local power and, on the other hand, to emphasize the changes brought by new actors. His work combines a cultural perspective and Habermas' notion of the public sphere, which he uses to understand the Brazilian political system but only since since the renewal of collective action (ROMÃO, 2010, p. 36-37). For Avritzer (2002), from the proclamation of the Brazilian Republic until the 1980s, there was a dominant political culture characterized by clientelism and patronage, and the latter was only gradually dismantled in the 1970s, with the emergence of autonomous urban associations.

Thus, in these studies, political institutions are mainly associated with 'traditional' forms of relations, inherited from the past. By mobilizing notions such as patrimonalism or clientelism, scholars have given the State and local powers an element of unity. As a consequence, the claims for participation formulated by social movements appear all the more democratic since the elites were apparently willing to reproduce the authoritarian and excluding order of an earlier era. This unifying perspective has been progressively undermined, in order to take into consideration the heterogeneity of both the State and civil society as well as their interaction.

\section{A changing view of the state: the promotion of progressive actors?}

The unifying and negative notion of the state has been much criticized by Brazilian scholars. Without denying the specificity of Brazilian State, several authors propose a more complex understanding of participatory institutions by taking into account the heterogeneity of the actors that promote them. Yet we can ask whether this change in perspective has really challenged the State-society dichotomy, or whether it has just reproduced it by expanding its frontiers. More precisely, the recognition of State heterogeneity has often attempted to understand the action of political individuals or organizations coming from or linked to civil society, such as the Workers Party. The 
consequence in participationist studies is that this party has been taken as a central actor of the rise of participatory democracy at the local level.

Dagnino, Olvera and Panfichi's seminal work (2006) on the democratic construction dispute in Latin America invites us to break with a homogenous conception of the State and civil society. Rejecting the idea that the second is necessarily a place of virtue while the first is the 'incarnation of evil', Dagnino, Olvera and Panfichi (2006) favor the idea that some civil society actors and part of political society can share a 'project', with frontiers that are not necessarily obvious, and that can overlap. From this perspective, they distinguish three projects. The first, is authoritarian, and is seen as dormant due to the disrepute brought on non-democratic forms of governing in South America. The other two are more up-to-date and promote civil society participation, although by a 'perverse confluence': the neoliberal one, oriented towards economic efficiency, and the democratic-participative project, which aims at deepening democracy with a broad and egalitarian inclusion of citizens in decision-making. It is interesting to note that the second, considered as better realized in Brazil in comparison to other Latin-American countries, is linked to specific actors, namely "social movements, trade unions, intellectuals, NGOs and others civil society organizations, together with left-wing political parties, in particular the Workers Party" (DAGNINO, OLVERA and PANFICHI, 2006, p. 49).

The integration of political actors in the scope of analysis of participatory democracy also marks a shift in Avritzer's perspective, developed in 'Participatory Institutions in Democratic Brazil' (2009). In contrast to his 2002 work, he analyses the 'changes in political society' occurring from the 1980s onwards (ROMÃO, 2010). But these changes are primarily linked to the Workers Party. The party's base was initially composed of urban social movements, and has been considered 'different' in the political field (KECK, 1991), a difference pointed out by Avritzer (2009):

The PT was crucial in bringing new practices of participatory politics from the periphery of the political system to the center [...]. The PT changed the patterns of democratic Brazil. At the level of political practices, the PT challenged several elements of the Brazilian political culture: [...] the century old practice of exchanging vote for political goods at the local level (LEAL, 1977 cited by AVRITZER, 2009, pp. 09 and 44).

This quotation shows that the recognition of political society's diversity does not necessarily imply a redefinition of how the State is depicted. On the contrary, 
because it represents the exception that proves the rules, the Workers Party and the experiments it implemented have been seen as a strong vehicle of change.

More generally, the Porto Alegre success story has helped consolidate the idea that the willingness of political actors is essential when it comes to understanding the unequal results of participatory budgeting. Indeed, several comparative studies have taken the variable 'political will' (AVRITZER and NAVARRO, 2003) or 'government commitment' (BORBA and LÜCHMANN, 2007) as a key for understanding the successes and failures of participatory budgeting models in Brazilian municipalities since 2000. Although this variable is questionable because it is based on a voluntaristic approach that neglects the rules and networks of the political system (LUCHMAN, 2014; SOUZA, 2001), its use in comparative studies has often led to the conclusion that non-leftist parties, and more precisely others than the Workers Party, are less engaged with participatory budgeting, even though this institution has spread throughout Brazil (WAMPLER, 2008).

Needless to say, the focus on the central role of the Workers Party in the creation and diffusion of participatory models has not meant uncritical support for its actions. Zander Navarro (2003) asks, for example, whether the participatory budgeting of Porto Alegre does not actually substitute traditional clientelism by partisan clientelism. Dagnino and Tatagiba (2010) ask whether clientelism is not reproduced in São Paulo (DAGNINO and TATAGIBA, 2010). Furthermore, Avritzer demonstrates that depending on the case studied the Workers Party can be divided on the participatory objectives (AVRITZER, 2009; 2012a).

Yet the experiments implemented by political actors from others parties participatory budgeting, councils or conferences - have often been seen as less 'participatory' than those led by the Workers Party, as for example the national conferences before Lula's government (AVRITZER, 2012b), or participatory budgeting created in Recife by a PMDB mayor in the late 1990s (SILVA, 2003).

Therefore, the renewed examination of the State and civil society in some way helps us to understand the action of the 'new' political and social protagonists, but without deepening our understanding of the dynamics of the political field or the civil society before the 1980s. In this respect, the critical and historical view proposed by Adrian Gurza Lavalle and José Szwako (2015) on the construction of a civil society in Brazil is interesting for two reasons. First, by referring to the existence of associationism 
since the nineteenth century and that various episodes of contentious action have marked the history of the Brazilian Republic, it breaks with the starting point of many participationist studies, that is, a unified State that suffocated collective action from the late nineteenth century until the 1980s. Secondly, by recalling that civil society cannot be analytically understood in total isolation from the State, be it authoritarian or democratic, it calls for a better understanding of their interrelations, a perspective also developed by others observers of Brazilian participatory institutions (ABERS and VON BULOW, 2011). This empirical and analytical move thus helps break down the idea of a radical novelty and autonomy of associationism in the 1980s. The next step is to probe the political sphere by examining its heterogeneity and the relation established with civil society before the 1980 s.

\section{Participatory democracy in a socio-historical perspective}

The repression, killing, torture and exile of opponents under the military regime mark a dark period in Brazil's history. Yet on an analytical level it is not heuristic to consider this period with a different lens to the one used to study democratic politics. More precisely, beyond the overall idea of generalized clientelism and patronage, several studies show that participation, as a practical category, has been used by both the military regime and its opponents. In order to take the historicity of participatory democracy into consideration, we need to retrace the history of this policy category, and to examine its uses by authoritarian actors.

\section{Beyond 'exceptions': studying the history of participation as a practical category}

One of the main difficulties in the study of participatory democracy is that the category on which it is based, 'citizen participation' is both practical and analytical (GURZA LAVALLE, 2011). Thus it is very tempting to make them overlap by considering that the experiments, institutions or practices, realized on behalf of participatory democracy, can only be referred to as such if they correspond to the scientific definition of democratic theories.

It is often by referring, implicitly or explicitly, to participation as an analytical category that the experiments in Brazil as elsewhere, have been evaluated and compared. Indeed, if the participatory budgeting of Porto Alegre has been set as the academic standard or even the 'ideal type' of participatory democracy, it is because it 
seemed to respond better to the philosophical ideal of popular sovereignty at the heart of participatory democracy (BACQUÉ and SINTOMER, 2011).

Clearly, this perspective is not incompatible with a close study of the discourse, practices and institutions that do not respond to the analytical ideal of democratic studies. When Dagnino (2007) questions the perverse confluence between the neoliberal and democratic-participative projects, she shows that the same words are used to describe very different practices. Similarly, by defining the scope of his study as "an outcome of institutions designed to promote participation" in order to differentiate participation and participatory institutions, Avritzer (2009, p. 04) proposes an interesting conceptual tool that helps to consider all the experiments realized in the name of participation.

Nevertheless these useful analytical perspectives are mainly used in relation to the democratic period. Indeed, it is by neglecting the study of the potential relation between the experiments realized before the 1980s, and the ones created after the end of the military regime, that the genesis of participatory democracy has been conceived $^{8}$. Of course, the 'vanguard' experiences are not ignored, especially the public audiences in Recife in the 1950s (CÉZAR, 1985), the voluntarist and participatory government in Lages (1977-1982) (ALVES, 1988), and the participatory programme in the city of Boa Esperança based on local development (1976-1982) (SOUZA, 1992), during the liberalization of the military regime. But these cases are mainly mentioned as islands of progress in an authoritarian and clientelist ocean. They are the exception that proves the rule, the first tremors of what will become a landslide in the 1980s.

However, several studies show that from the 1950s to the late 1970s, the idea of the poor's 'participation', was driven not only by progressive actors, but also by other, very different, protagonists. The studies of the ideology and practices of 'community development' - a current of thought considered by Bacqué and Sintomer (2011) and part of the 'participatory patchwork' - provided potential avenues of investigation to redefine the genesis of participatory democracy (AMMAN, 1985; SOUZA, 1987; WANDERLEY, 1993).

The community development school of thought influential in the 1950 s to

\footnotetext{
${ }^{8}$ Except from an article by Gurza Lavalle (2011) which proposes an interesting socio-historical analysis.
} 
late-1970s rests on the idea of 'popular' or 'community' participation. To understand what participation means in the framework of community development, Amman (1985) studies the history and uses of this current of thought. It was introduced in Brazil through three actors. First, the international organizations, and more precisely the U.N. Economic and Social Council. In the context of the Cold War it recommended the use of community development in order to deal with the rural social question and to limit the radicalization of the rural population, especially in the 1950 s. Second, the Roman Catholic Church had progressively embraced the idea of popular consciousness and developed several experiments based on community participation, such as in São Paulo de Potengi in 1949, especially in the Brazilian Northeast, where young Catholic men helped create collective infrastructures and community organizations (ROCHA, 2006). Third, a new professional group emerged at the frontier of international and Catholic interventions - social workers and relied on community development school of thought to justify their actions (AMMAN, 1985; SOUZA, 1987).

Given the heterogeneity of the actors' involved, different types of experiments were realized from the 1950s to the early 1960s. Amman distinguishes two main trends: the first is referred to as 'orthodox' and strives to maintain the political order and facilitate the 'national-developmentalist' policies; the second, 'heterodox', is oriented towards challenging the social and political structures and promoting the politicization of the poor (AMMAN, 1985; WANDERLEY, 1993).

The 1964 military coup and the inauguration of an authoritarian regime did not lead to an abrupt break with the ideal of community development but, on the contrary, institutionalized it as a tool for efficient policy implementation at the local level. Participation therefore had an orthodox meaning and was seen as a way to implement social policies. With the creation of a coordination of community development programmes (CPDC) under the Ministry of the Interior in 1970, and five years later, the adoption of the National Plan of Urban Social Center (PNCSU), 'communities' participation is sought and promoted by the federal government and often implemented by social workers at the municipal level. The goal of the PNCSU was to provide basic social services in urban areas, in response to the problems generated by rapid urbanization. It also relied on community development understood as, 
the awareness by the individual of the possibility and need for his participation in resolving problems and in defining objectives that look at the needs of the whole population and for the harmonious development of their living environment - the urban one (PNCSU cited by BORBA, 1991, p. 408).

At the local level, this programme and its participatory ambitions stimulated the creation of other programmes based on the idea of organized group consultation. An example is Recife during the period of military rule and its mayor Gustavo Krause (1979-1982), who wanted to stimulate: "the community spirit by urban social centers and by reinforcing grassroots associations, because without participation, society is anemic, and without mobilization, individuals can't become a master of their own destiny" (KRAUSE cited by ASSIES, 1991, p. 143).

Beyond the case of Recife, with the creation of community centers, named 'barracões', we should mention the city of Londrina studied by Ricardo de Jesus Silveira (1997) where the implementation of the PNCUS led to the creation of twentyeight associations, influenced by the local housing authority (SILVEIRA, 1997, p. 95).

Naturally, these few cases could be seen as a good counter example of the idea that citizen participation was relevant during the military regime, because in both cases, public institutions and actors played an important role in the creation or mobilization of urban associations. They could illustrate the traditional State patronage of society that prevailed until the birth of an autonomous civil society. But in the final section, I would like to argue that leaving aside these cases, and the national framework that justifies them, would be analytically inadequate.

\section{Continuity or break: dealing with past experiments?}

It is interesting to note that from the 1950s, the idea of 'popular' or 'community' participation emerged in different stages and was institutionalized in the political field in the 1970s, during the military regime. This category was not understood in exactly the same way as after the return to democracy, but the mere fact that the notion of participation was significant in the discourse of an authoritarian regime, and that it was realized by some procedures, merits closer investigation. After all, today, if some experiments made on behalf of participation, and evaluated as merely consultative or legitimizing tools, are part of the scope of participationist 
studies, why should scholars exclude the experiments made under military rule? Institutions created in the Maghreb (ALLAL, 2016), or China (CHARON, 2010) show that the discourse of participatory democracy can also flourish under authoritarian regimes.

Hence, two analytical orientations help us rethink the Brazilian genesis of participatory democracy, in order to determine whether, and to what extent, the experience of the 1960s and 1970s differs radically from the experiments made after the 1980s, or whether on the contrary, these are not the roots that enabled the diffusion of participatory democracy in the 1980s.

This first line of analysis is to apply the renewed notion of the State, considering its heterogeneity, to the period prior to the 1980s. The objective of the PNCUS, the cases of Recife and Londrina, but also Lages and Boa Esperança, show that behind the authoritarian regime, especially from liberalization onwards, political actors refer to participation giving it different meanings. In Londrina, participation was understood as a tool to guarantee the efficiency of social policy, in accordance with national goals. The case of Lages shows that the same category had been used simultaneously, with a more critical objective, that of 'empowering' the poor. These examples show that even under the military regime, there was a certain diversity among actors and ways of governing, especially at the local level and in cities that were not part of 'national security areas'. An explanation can be found in the bipartite system created by the military regime. Although artificial and controlled, it allowed some progressive elites to enter, or to remain, in the political field under the umbrella of a growing $\mathrm{MDB}^{9}$, as for example in Lages. Moreover, we may ask ourselves whether the meaning given to participation - a tool for policy efficiency on the one hand and a means of emancipation on the other - does not prefigure the 'perverse confluence' studied by Dagnino (2007).

The second orientation would be to take the discourse of participation under the military regime seriously. Why was community participation appreciated when representative procedures were under strict control? And what were the effects of such a discursive framework on the actions of representative and bureaucratic protagonists? An analysis that only identifies the historical will of State actors to co-opt

9 The Movimento Democrático Brasileiro (MDB) was the authorized opposition party to the military regime. 
or control civil society may miss the force of the 'fiction'; that is, the accepted narrative in a given period and a specific context, on which the idea of participation rests. In his study of the construction of the representative system in England and North America, Edmund Morgan (1988) reminds us that,

"all government rests on the consent, however obtained, of the governed [...]. The success of government thus requires the acceptance of fictions, requires the willing suspension of disbelief, requires us to believe that the emperor is clothed even though we can see that he is not" (MORGAN, 1988, p. 13).

For Morgan (1988), it is precisely the fiction of popular sovereignty that permitted the few to govern the many in Anglo-American representative systems. Yet Morgan's main contribution (1988) is to show that this fiction was not merely a way to legitimize inequalities and the people's exclusion from the political sphere; the fiction of popular sovereignty also limited representation itself:

"Representation is itself a fiction, and like others fictions it could restrict the action of those who espoused it. Because they claimed to represent all subjects, the gentlemen who sat at Westminster had to act not merely for their own kind but for everyone else" (MORGAN, 1988, p. 23).

This critical perspective, that considers the performative force of discourse, could help determine whether, and to what extent, the participatory repertoire developed during the military regime influenced later experiments in participation.

Beyond the unifying idea of an authoritarian and clientelistic political culture, these two orientations thus 'bring the State into' the analysis. Hence, if we accept that civil society has to interact with political institutions, either by cooperating or by challenging it (GURZA LAVALLE and SZWAKO, 2015), a better understanding of the second would help to define more precisely how participatory democracy has been placed at the heart of policy-making in the democratic period. 


\section{Conclusion}

This article questions the movement-based genesis of participatory democracy in Brazil by analyzing the notion of the history of political institutions on which it rests. It shows that the narrative that defines the birth of civil society as the starting point for the participatory ideal rests on a simplified representation of the Brazilian political sphere before the 1980s. Because it is only perceived in terms of its 'traditional ills', the State seems to have no influence on the rise of the participatory ideal.

This negative representation of political institutions is not only an outcome of participationist studies. The 'classic works' of Brazilian political sociology played a key role in showing that the representative system followed a deviant path compared to a somewhat idealized Western notion of State formation. The first wave of participatory democracy analysis rests partly on these classical studies when defining the characteristics of the construction of the Brazilian State. The result is that political institutions and actors are reduced to the notions of clientelism, patrimonialism and patronage, without a systematic analysis of the historicity of these categories.

This unifying vision of State dynamics has been progressively challenged in order to have a better understanding of changes within the political realm, and this analytical revision has mainly been applied to the democratic period, from the $1980 \mathrm{~s}$ onwards. The experiments realized on behalf of 'popular' and 'community' participation from the 1950s to the 1970s, partly by federal and local agencies, have been neglected in the analyses. Hence, this article proposes lines of inquiry to investigate the uses of participation, as a practical category in a socio-historical perspective, such as the meaning that participation had for the military regime and the consequences of the uses of this category on its institutional role.

More generally, the simplified conception of political institutions and actors before the 1980s that prevails in participationist studies, questions the conclusion reached on some practices considered particularly successful, such as participatory budgeting in Porto Alegre. How do we understand the 'changes' and 'breaks' generated by participatory institutions if the starting point for the comparison is analytically inappropriate? We can ask whether the enthusiastic conclusions, e.g. that clientelism has been challenged, do not altogether depend on the very general conception of the functioning of the political institutions that appeared to prevail before the 1980s.

Therefore, this review article invites us to seek a better understanding of the 
history of participatory democracy over time. This does not mean that from the $1950 \mathrm{~s}$ onwards, the same conception of participation prevailed. In my $\mathrm{PhD}$ thesis I tested the hypothesis that if, from the 1950s to the 1970s, participation was a tool for social and economic 'development', after the collapse of the military regime, it started to be framed as an institutional issue, linked to the decision-making process (SA VILAS BOAS, 2012). Gurza Lavalle (2011) has proposed an interesting reflection recalling that if the notion of 'popular participation' was favored in the 1960s, the legitimate category is now 'citizen participation', a shift that reveals changes in the conception of citizen involvement. He argues that the links between these two periods still need to be investigated (GURZA LAVALLE, 2011). Indeed, historical analysis on past experiments would increase our actual understanding of what participatory democracy means, and has meant, in Brazil.

Revised by Clare Tame Submitted on January 30, 2016 Accepted on October 21, 2016

\section{References}

ABERS, Rebecca and VON BULOW, Marisa (2011), Movimentos sociais na teoria e na prática: como estudar o ativismo através da fronteira entre Estado e sociedade? Sociologias. Vol. 13, № 28, pp. 52-84.

ALLAL, Amin (2016), Penser global, agir dans un bocal. Participation locale, régulation néo-libérale et situation autoritaire en Tunisie (2006-2010). Gouvernement et Action Publique. Vol. 02, $\mathrm{N}^{\circ}$ 02, pp.153-181.

ALVES, Marcio (1988), A força do povo: democracia participativa em Lages. São Paulo: Brasiliense. 150pp.

AMMAN, Safira Bezerra (1985), Ideologia do desenvolvimento da comunidade no Brasil. São Paulo: Cortez. 176pp..

ASSIES, Willem (1991), To get out of the Mud. Neighborhood associativism in Recife1964-1968. Amsterdam : CEDLA/ Latin American Studies. 332pp..

AVRITZER, Leonardo (2002), Democracy and the public sphere in Latin America. Princeton: Princeton University Press. 208pp..

AVRITZER, Leonardo (2009), Participatory institutions in democratic Brazil. Washington: Woodrow Wilson Centre Press. 224pp.

AVRITZER, Leonardo (2012a), The different design of public participation in Brazil: deliberation, power sharing and public ratification. Critical Political Studies. Vol. 06, $\mathrm{N}^{\circ} 02$, pp. 113-127. 
AVRITZER, Leonardo (2012b), National conferences in Brazil. A new participatory political model. Books and Ideas. Available at http://www.booksandideas.net/National-Conferences-in-Brazil.html. Acessed on August 14, 2016.

AVRITZER, Leonardo and NAVARRO, Zander (2003), A inovação democrática no Brasil : o orçamento participativo. São Paulo: Cortez. 334pp..

BACQUÉ, Marie-Hélène and SINTOMER, Yves (2011), Le temps long de la participation. In: La démocratie participative. Histoire et Généalogie. Edited by BACQUÉ, MarieHélène and SINTOMER, Yves. Paris: La Découverte, pp. 09-35.

BADIE, Bertrand (1992), L'Etat importé. Essai sur l'occidentalisation de l'ordre politique. Paris: Fayard. 334pp..

BARBER, Benjamin R. (1984), Strong democracy: participatory politics for a new age. Berkeley: University of California Press. 320pp..

BENEVIDES, Maria Victoria de M. (1996), A cidadania ativa. Referendo, plebiscito e iniciativa popular. São Paulo: Ática. 208pp..

BLATRIX, Cécile (2000), La « démocratie participative», de mai 1968 aux mobilisations anti-TGV. Processus de consolidation d'institutions sociales émergentes. Doctoral thesis. University of Paris 1.

BORBA, Julian and LÜCHMANN, Lígia Helena Hahn (2007), Orçamento participativo: análise das experiências desenvolvidas em Santa Catarina. Florianópolis: Insular. 224pp..

BORBA, Sheila Villanova (1991), A produção de equipamentos urbanos como alternativa de política social - o Programa Nacional de Centros Sociais Urbanos. Ensaios FEE. Vol. 12, $\mathrm{N}^{\circ} 02$, pp. 403-421.

CAMPANTE, Rubens (2003), O patrimonialismo em Faoro e Weber e a sociologia brasileira. Dados. Vol. 46, № 01, pp. 153-193.

CÉZAR, Maria do Céu (1985), As organizações populares no Recife: trajetória e articulação política (1955-1964). Cadernos de Estudos Sociais. Vol. 01, № 02, pp. 161 182.

CHARON, Paulo (2010), Participation contre démocratie. La diffusion des sondages délibératifs en Chine. Le Banquet. $\mathrm{N}^{\circ}$ 27. Available at http://www.revuelebanquet.com. Acessed on december 17, 2016.

CHIAROTTI, Césario Ana Cleide (1986), Poder e partidos numa cidade média brasileira. Um estudo de poder local : Londrina-PR. 1934-1979. Doctoral thesis. Universidade de São Paulo. 
COSTA, Frederico Carlos de Sá (2005), Oliveira Vianna e o problema institucional brasileiro. Cadernos de Sociologia e Política. Vol. 08 , pp. 37-53.

DAGNINO, Evelina (1994), Os anos 90: Política e sociedade no Brasil. Edited by DAGNINO, Evelina. São Paulo: Editora Brasiliense. 174pp..

DAGNINO, Evelina (2007), Citizenship: a perverse confluence. Development in Practice. Vol. 17, N $4-5$, pp. 549-556.

DAGNINO, Evelina; OLVERA, Alberto J. and PANFICHI, Aldo (2006), Para uma outra leitura da disputa pela construção democrática na America Latina. In: A disputa pela construção democrática na America Latina. Edited by DAGNINO, Evelina; OLVERA, Alberto J. and PANFICHI, Aldo. São Paulo: Editora Paz e Terra/Unicamp. pp. 13-91.

DAGNINO, Evelina and TATAGIBA, Luciana (2010), Mouvements sociaux et participation institutionnelle: répertoires d'action collective et dynamiques culturelles dans la difficile construction de la démocratie brésilienne. Revue internationale de politique comparée. Vol. 17, № 02, pp. 167-185.

DAVIDOFF, Carlos Henrique (1982), A ideologia da modernização em Gilberto Freyre e Oliveira Vianna. Perspectivas. Vol. 05, pp. 29-38.

DOIMO, Ana Maria (1995), A vez e a voz do popular: movimentos sociais e participação política no Brasil pós-70. Rio de Janeiro: Relume-Dumara. 352pp..

DUARTE, Nestor (1939), A ordem privada e a organização política nacional. São Paulo: Nacional. 242pp..

FAORO, Raymundo (2001), Os donos do poder. Formação do patronato político brasileiro. São Paulo: Editora Globo. 944pp..

FEDOZZI, Luciano Joel (1997), Orçamento participativo - reflexões sobre a experiência de Porto Alegre. Porto Alegre: Tomo Editorial. 253pp..

FEDOZZI, Luciano Joel (2001), Práticas inovadoras de gestão urbana: o paradigma participativo. Revista Paranaense de Desenvolvimento. № 100, pp. 93-107.

FEDOZZI, Luciano Joel and MARTINS, André Luis Borges (2015), Trajetória do orçamento participativo de Porto Alegre: representação e elitização política. Lua Nova. Vol. 95, pp. 181-223.

FORJAZ, Maria Cecília Spina (1997), A emergência da ciência política no Brasil. Aspectos institucionais. Revista Brasileira de Ciências Sociais. Vol. 12, № 35, pp. 101-120.

FORTUNATO, Maria Lucinete (2000), O coronelismo e a imagem do coronel: de símbolo a simulacro do poder local. Doctoral thesis. Universidade Estadual de Campinas.

GOIRAND, Camille (2010), Penser les mouvements sociaux d'Amérique latine. Revue française de science politique. Vol. 60, $\mathrm{N}^{\circ} 03$, pp. 445-466. 
GURZA LAVALLE, Adrián (2011), Participação: valor, utilidade, efeitos e causa. In: Efetividade das instituições participativas no Brasil: estratégias de avaliação. Edited by PIRES, Roberto Rocha C.. Brasília: IPEA/Diálogos para o desenvolvimento. pp. 3342.

GURZA LAVALLE, Adrián and SZWAKO José (2015), Sociedade civil, Estado e autonomia: argumentos, contra-argumentos e avanços no debate. Opinião Pública. Vol. 21, $\mathrm{N}^{\circ} 01$, pp. 157-187.

HIRSCHMAN, Albert (1991), The rhetoric of reaction: perversity, futility, jeopardy. Cambridge: The Belknap Press of Harvard University Press. 224pp..

HOLANDA, Sergio Buarque de (2006), Raízes do Brasil. São Paulo: Companhia da Letras. 226pp.

JOANA, Jean (2000), La sociologie historique face au local. Enjeux problématiques de l'analyse de l'action publique municipale sous la IIlème République. In: Les méthodes au concret. Edited by CURAPP. Paris: Presses Universitaire de France. pp. 299-319.

KECK, Margaret (1991), PT: a lógica da diferença. O Partido dos Trabalhadores na construção da democracia brasileira. São Paulo: Ática. 184pp..

KEINERT, Fábio Cardoso and SILVA, Dimitri Pinheiro (2010), A gênese da ciência política brasileira. Tempo Social. Vol. 22, № 01, pp. 79-98.

KIRSCHNER, Ana Maria and GOMES, Eduardo Rodrigues (2008), Les sciences sociales au Brésil aujourd'hui: des questions structurelles aux nouvelles questions sociales. Sociologie Pratique. Vol. 02, № 17, pp. 123-134.

LAMOUNIER, Bolivar (2005), Da independência a Lula: dois séculos de política brasileira. São Paulo: Augurium Editora. 319pp..

LEAL, Victor Nunes (1975), Coronelismo, enxada e voto: o município e o regime representativo no Brasil. São Paulo: Alfa-Ômega. 303pp..

LUCHMANN, Lígia Helena Hahn (2014), 25 anos de Orçamento Participativo: algumas reflexões analíticas. Política e Sociedade. Vol. 13, № 28, pp. 167-197.

MORGAN, Edmund (1988), Inventing the people: the rise of popular sovereignty in England and America. New York: Norton \& Co. 320pp..

MOTA, Carlos Guilherme (2008), Ideologia da cultura brasileira (1933-1974). São Paulo: Editora 34. 424pp.

NAVARRO, Zander (2003). “O 'Orçamento Participativo' de Porto Alegre (1989- 2002): Um conciso comentário crítico." In: A inovação democrática no Brasil: o orçamento participativo. Edited by AVRITZER Leonardo and NAVARRO Zander. São Paulo: Cortez. pp. 89-128. 
PATEMAN, Carole (1970), Participation and democratic theory. Cambridge: Cambridge University Press. 132pp..

PÉCAUT, Daniel (1990), Os intelectuais e a política no Brasil: entre o povo e a nação. São Paulo: Ática. 335pp..

REIS, Fábio Wanderley (1991), 0 tabelião e a lupa: teoria, método generalizante e idiografia no contexto brasileiro. Revista Brasileira de Ciências Sociais. Vol. 06, № 16, pp. 27-42.

REIS, Fábio Wanderley (1978), Os partidos e o regime: a lógica do processo eleitoral brasileiro. São Paulo: Símbolo. 315pp..

ROCHA, Maria de Sá (2006), São Paulo de Potengi: uma cidade, seu pároco e suas práticas educativas. Doctoral thesis. Universidade Federal do Rio Grande do Norte.

ROMÃO, Wagner de Melo (2010), Nas franjas da sociedade política: estudo sobre o orçamento participativo. Doctoral thesis. Universidade de São Paulo.

SA VILAS BOAS, Marie-Hélène (2012), Du quartier à l'Etat. Sociologie des publics des dispositifs participatifs brésiliens. Le cas des conférences municipales des femmes à Recife et de Londrina. Doctoral thesis. University Aix-Marseille.

SADER, Eder (1988), Quando novos personagens entraram em cena: experiências, lutas e falas dos trabalhadores na grande São Paulo (1970-1980). São Paulo: Paz e Terra. 341pp..

SANTOS, Wanderley Guilherme dos (1979a), The calculus of conflict: impasse in Brazilian politics and the crisis of 1964. Doctoral thesis. University of Stanford.

SANTOS, Wanderley Guilherme dos (1979b), Cidadania e justiça: a política social na ordem brasileira. Rio de Janeiro: Editora Campus. 138pp..

SANTOS, Wanderley Guilherme dos (1998), Décadas de espanto e uma apologia democrática. Rio de Janeiro: Editora Rocco. 196pp..

SCHWARTZMAN, Simon (1988), Bases do autoritarismo brasileiro. Rio de Janeiro: Campus. 290pp..

SILVA, Tarcisio da (2003), Da participação que temos à que queremos: o processo do Orçamento Participativo na cidade de Recife. In: A inovação democrática no Brasil : o orçamento participativo. Edited by AVRITZER, Leonardo and NAVARRO, Zander. São Paulo: Cortez, pp. 331-385.

SILVEIRA, Ricardo de Jesus (1997), As associações de moradores e a construção do espaço público: um exercício de cidadania. Estudo sobre o movimento de associações de moradores em Londrina. Doctoral thesis. Universidade de São Paulo. 
SOUZA, Celina (2001), Construção e consolidação de instituições democráticas: papel do orçamento participativo. São Paulo em Perspectiva. Vol. 15, № 04, pp. 84-97.

SOUZA, Maria Luiza de (1987), Desenvolvimento da comunidade e participação. São Paulo: Cortez Editora. 231pp..

SOUZA, Herbert José (1992), Município de Boa Esperança: participação popular e poder local. In: Alternativas populares da democracia: Brasil, anos 80. Edited by MOISES, José. Petrópolis : Vozes/CEDEC. pp. 92-120.

VALE, Teresa (2008), Cidadania regulada: uma exploração crítica do conceito. Anais do 6 encontro da ABCP. Campinas.

VIANNA, Francisco José Oliveira (1923), Evolução do povo brasileiro. São Paulo: Monteiro Lobato. 275pp..

VIANNA, Francisco José Oliveira (1949), Instituições políticas do Brasil. Vol. I e II. Rio de Janeiro: José Olympio. 652pp.

VIANNA, Francisco José Oliveira (1974), Problemas de política objectiva. Rio de Janeiro: Record. 194pp..

WAMPLER, Brian (2008), A difusão do Orçamento Participativo brasileiro: 'boas práticas' devem ser promovidas? Opinião Pública. Vol. 14, № 01, pp. 65-95.

WAMPLER, Brian (2015), Activating democracy in Brazil: popular participation, social justice and interlocking institutions. Notre Dame: University of Notre Dame Press. 312pp..

WANDERLEY, Mariangela Belfiore (1993), Metamorfoses do desenvolvimento de comunidade. São Paulo: Cortez Editora. 200pp..

WEFFORT, Francisco (1980), o populismo na política brasileira. Rio de Janeiro: Paz e Terra. 181pp.. 